\title{
HUBUNGAN KOMPETENSI PEDAGOGIK DAN KEMAMPUAN MENGELOLA PEMBELAJARAN PADA GURU SD SEKECAMATAN PACITAN
}

\author{
Nanda Eka Saputri ${ }^{1}$, Kartika Chrysti Suryandari $^{2}$, Ratna Hidayah ${ }^{3}$ \\ Universitas Sebelas Maret \\ nandaeka@student.uns.ac.id
}

\section{Article History}

accepted 1/11/2021

approved 1/12/2021

published 31/12/2021

\begin{abstract}
The study aimed to prove positive correlation between pedagogical competence and classroom management skill to public elementary school teachers in Pacitan Sub-district and to measure the contribution of pedagogical competence and classroom management skill to elementary school teachers in Pacitan Sub-district. It was correlational quantitative method. The population were 222 elementary school teachers of first to sixth grade and the samples were 144 teachers. Data collection techniques used questionnaire. The prerequisite test used linearity and normality tests. Data analysis used a simple correlation test and adjusted $R$ square. The results showed that there was positive correlation between pedagogical competence and classroom management skill. The correlation value was 0,335 and it indicated as moderate correlation. Pedagogical competence contributed $11.2 \%$ on classroom management skill. High pedagogical competence was closely related to how teachers: understanding student characteristics, understanding theories and learning principles, developing curriculum, presenting enlightened learning, developing student potency, having good communication to students, and conducting evaluations and assessments measuring the success of learning process. Therefore, if teacher's pedagogical competence was good, the classroom management would be maximized. Keywords: pedagogical competence, classroom management skill
\end{abstract}

\begin{abstract}
Abstrak
Penelitian ini bertujuan untuk membuktikan adanya hubungan positif yang signifikan antara kompetensi pedagogik dan kemampuan mengelola pembelajaran pada guru SD serta menghitung besarnya sumbangan kompetensi pedagogik dan kemampuan mengelola pembelajaran pada guru SD sekecamatan Pacitan. Penelitian ini merupakan penelitian kuantitatif korelasi. Populasinya 222 guru dan sampel sebanyak 144 guru. Teknik pengumpulan data yaitu dengan menggunakan angket. Uji prasyarat meggunakan uji normalitas dan linieritas. Analisis data penelitian ini yaitu uji korelasi sederhana dan sumbangan efektif (SE). Penelitian ini menghasilkan kesimpulan bahwa terdapat hubungan positif yang signifikan antara kompetensi pedagogik dan kemampuan mengelola pembelajaran dengan tingkat korelasi sedang yaitu 0,335 dan sumbangan variabel kompetensi pedagogik dan kemampuan mengelola pembelajaran yaitu 11,2\%. Berdasarkan hasil penelitian tersebut dapat disimpulkan bahwa terdapat hubungan positif yang signifikan antara kompetensi pedagogik dan kemampuan mengelola pembelajaran pada guru SD sekecamatan Pacitan, artinya semakin tinggi kompetensi pedagogic seorang guru maka kemampuan guru dalam mengelola pembelajaran juga akan semakin baik.
\end{abstract}

Kata kunci: Kompetensi Pedagogik, Kemampuan Mengelola Pembelajaran 


\section{PENDAHULUAN}

Kompetensi pedagogik menurut (Hamdani, 2017 : 72) merupakan suatu hal yang erat kaitannya dengan ilmu mendidik (kegiatan belajar mengajar). Kompetensi pedagogik tentunya sangat diperlukan oleh guru dalam mengelola pembelajaran, kompetensi tersebut meliputi kemampuan pemahaman terhadap peserta didik, perancangan serta pelaksanaan pembelajaran, penilaian dan evaluasi hasil belajar, dan pengembangan peserta didik untuk mengaktualisasikan berbagai potensi yang ada dalam diri siswa (Widyawahyuni, 2015 : 13). Kompetensi pedagogik sangat erat kaitannya dengan kegiatan belajar mengajar. oleh karena itu kompetensi pedagogik memiliki hubungan yang erat dengan kemampuan guru dalam mengelola pembelajaran.

Pengelolaan pembelajaran merupakan suatu tindakan yang harus dilakukan oleh guru dalam proses pembelajaran agar dapat membantu mempermudah jalannya proses pembelajaran sesuai yang diharapkan (Pamela, dkk : 2019 8). Kompetensi merupakan tolak ukur untuk menggambarkan kemampuan guru dalam bekerja. Semakin tinggi kompetensi yang dimiliki guru tentunya akan memberikan dampak yang signifikan terhadap ketercapaian tujuan pembelajaran, begitupun sebaliknya jika kompetensi yang dimiliki guru terbilang rendah maka kemampuan guru dalam mengelola pembelajaran akan kurang maksimal

Di Pacitan sendiri kompetensi pedagogik yang dimiliki oleh guru masih tergolong rendah hal ini dibuktikan dengan hasil Uji Kompetensi Guru (UKG) yang diperoleh dari Pacitanku.com dari total sebanyak 5674 peserta UKG di 12 kecamatan di Pacitan, tercatat hanya 40,5 persen guru yang melampaui ambang batas diatas 5,5 . Dengan hasil tersebut, berarti lebih dari separuh peserta atau sebanyak 59,5 persen guru masih memiliki kompetensi dibawah standar yang ditetapkan Kementerian Pendidikan dan Kebudayaan (Kemdikbud), dari data diatas dapat diketahui bahwa kompetensi yang dimiliki guru di Pacitan masih tergolong rendah.

Data tersebut sejalan dengan data yang termuat dalam naskah publikasi oleh Srijani $(2013$ : 4) yang berjudul Pengelolaan Uji Kompetensi Pedagogi Guru SD Di Kabupaten Pacitan, bahwa kompetensi pedagogik guru SD di Pacitan masih belum seperti yang diharapkan, hal tersebut ditunjukkan dengan belum mampunya guru dalam menyusun rancangan pembelajaran yang sesuai dengan kondisi peserta didik dan lingkungan, belum mampu melaksanakan kegiatan pembelajaran yang bermakna sesuai dengan kebutuhan peserta didik, belum mampu membuat dan menggunakan berbagai materi pembelajaran maupun sumber belajar yang sesuai dengan karakteristik peserta didik, serta guru banyak yang belum mampu memanfaatkan media yang relevan, apalagi memanfaatkan teknologi informasi dan komunikasi guna kepentingan pembelajaran.

Rendahnya kompetensi pedagogik guru tersebut tentunya juga berpengaruh terhadap kemampuan mengelola pembelajaran pada guru SD sekecamatan Pacitan. Berdasarkan hasil pra survey berupa wawancara yang telah dilakukan dengan kepala sekolah maupun beberapa guru di sekolah dasar di Kecamatan Pacitan diketahui bahwa kemampuan yang dimiliki guru dalam mengelola pem2:belajaran belum maksimal. Rendahnya keterampilan guru dalam mengelola pembelajaran tersebut ditunjukkan dengan adanya beberapa hal, diantaranya: (1) banyak guru yang belum mampu memanfaatkan media pembelajaran berbasis ilmu pengetahuan dan teknologi,; (2) masih adanya guru yang hanya menggunakan RPP seadanya dan tidak mengembangkannya berdasarkan situasi yang ada; (3) sebagian guru yang hanya mengandalkan metode konvensional dalam mengajar; (4) sebagian guru hanya menggunakan media pembelajaran yang telah ada tanpa inisiatif untuk membuat yang lebih menarik; (5) kurangnya pemahaman guru terhadap kondisi siswa.

Berdasarkan uraian di atas, penting kiranya dilakukan penelitian untuk mengetahui ada tidaknya hubungan antara kompetensi pedagogik dan kemampuan 
mengelola pembelajaran serta menghitung besarnya sumbangan kompetensi pedagogik dan kemampuan mengelola pembelajaran pada guru SD sekecamatan Pacitan melalui penelitian kuantitatif dengan judul "Hubungan Kompetensi Pedagogik dan Kemampuan Mengelola Pembelajaran pada Guru SD sekecamatan Pacitan".

Tujuan penelitian ini adalah: (1) membuktikan adanya korelasi positif antara kompetensi pedagogik dengan kemampuan mengelola pembelajaran pada guru SD sekecamatan Pacitan. (2) mengukur besarnya sumbangan kompetensi pedagogik terhadap kemampuan mengelola pembelajaran pada guru SD sekecamatan Pacitan.

\section{METODE}

Penelitian ini merupakan penelitian kuantitatif dengan metode korelasi. Sampel yang digunakan dalam penelitian ini yaitu guru kelas 1 sampai dengan kelas 6 di dua puluh empat SD sekecamatan yang dipilih secara acak dengan teknik cluster random sampling, sehingga menghasilkan 6 SD terpilih yang menjadi sample penelitian. Pengambilan sampel dengan cara cluster random sampling adalah dengan melakukan randomisasi terhadap kelompok (sekolah), bukan terhadap subjek secara individual. Sekolah yang digunakan pada penelitian ini yaitu SDN Ponggok, SDN Sambong 1, SDN Sambong 2, SDN Pucangsewu, SD Alam Pacitan, SD Sidoharjo, SDN Pacitan, SDN Sukoharjo, SDN Baleharjo 1, SDN Baleharjo 2, SDN Sirnoboyo 1, SDN Tanjungsari, SDN Purworejo, SDN Sedeng 1, SD Insan Cendekia, SDN Arjowinangun, SDN Ploso 1, SDN Widoro, SDN Kayen 1, SDN Kayen 2, SDN Banjarsari, SDN Kembang, SDN Sumberharjo, SDN Bangunsari.

Teknik pengumpulan data pada penelitian ini menggunakan angket, yaitu angket kompetensi pedagogik dan angket kemampuan mengelola pembelajaran. Uji prasyarat analisis data yang digunakan yaitu uji normalitas dan uji linieritas. Analisis data yang digunakan yaitu korelasi sederhana dan sumbangan efektif (SE) dengan taraf signifikansi $5 \%$.

\section{HASIL DAN PEMBAHASAN}

Penelitian ini dilakukan dengan memberikan angket kepada guru kelas 1 sampai dengan guru kelas 6 di dua puluh empat SD di Kecamatan Pacitan. Angket ini berisi tentang indikator yang berhubungan dengan kompetensi pedagogik dan kemampuan mengelola pembelajaran sehingga dapat mengukur tinggi rendahnya kompetensi pedagogik maupun kemampuan mengelola pembelajaran yang dimiliki oleh guru SD se-Kecamata Pacitan. Prasyarat data terpenuhi yaitu data berasal dari populasi berdistribusi normal dan terdapat hubungan linear antara kompetensi pedagogik dengan kemampuan mengelola pembelajaran pada guru SD sekecamatan Pacitan. Data hasil penelitian berasal dari data berdistribusi normal yang ditunjukkan dengan nilai signifikansi kompetensi pedagogik 0,200 dan kemampuan mengelola pembelajaran yakni 0,200 . Kedua nilai signifikansi data menunjukkan nilai $>0,05$ sehingga data tersebut berasal dari populasi berdistribusi normal. Data dikatakan terdapat hubungan linear antara variabel $X$ dan $Y$ jika $p$ value Deviation from Linearity $>0,05$. Nilai $p$ value Deviation from Linearity yaitu $0,439>0,05$ sehingga terdapat hubungan linear antara kompetensi pedagogik dan kemampuan mengelola pembelajaran pada guru SD sekecamatan Pacitan.

Korelasi antara kompetensi pedagogik dan kemampuan mengelola pembelajaran diuji menggunakan uji korelasi pearson product moment. Uji Korelasi menggunakan bantuan aplikasi SPSS versi 21. Hipotesis yang digunakan adalah $\mathrm{HO}=$ tidak ada hubungan antara kompetensi pedagogik dan kemampuan mengelola pembelajaran pada guru SD sekecamatan Pacitan dan $\mathrm{H} 1=$ ada hubungan antara kompetensi pedagogik dan kemampuan mengelola pembelajaran pada guru SD sekecamatan Pacitan 
Tabel 1 Distribusi Frekuensi kompetensi pedagogik dan kemampuan mengelola pembelajaran

\begin{tabular}{ccccc}
\hline No & $\begin{array}{c}\text { Kompetensi Pedagogik } \\
\text { Interval }\end{array}$ & $\begin{array}{c}\text { Kemampuan } \\
\text { Frekuensi }\end{array}$ & $\begin{array}{c}\text { Mengelola Pembelajaran } \\
\text { Interval }\end{array}$ & $\begin{array}{c}\text { Frekuensi } \\
\text { Frekn }\end{array}$ \\
\hline 1 & $77-79$ & 3 & $75-77$ & 3 \\
2 & $80-82$ & 8 & $78-80$ & 10 \\
3 & $83-85$ & 16 & $81-83$ & 18 \\
4 & $86-88$ & 27 & $84-86$ & 28 \\
5 & $89-91$ & 36 & $87-89$ & 36 \\
6 & $92-94$ & 31 & $90-92$ & 26 \\
7 & $95-97$ & 14 & $93-96$ & 15 \\
8 & $98-100$ & 9 & $97-100$ & 8 \\
& Total & 144 & Total & 144 \\
\hline
\end{tabular}

Tabel 2 Hasil Analisis Korelasi kompetensi pedagogik dan kemampuan mengelola pembelajaran

\begin{tabular}{llrr}
\hline & \multicolumn{1}{c}{ Correlations } & \\
& & $\begin{array}{c}\text { Kemampuan } \\
\text { Kompetensi } \\
\text { Pedagogik }\end{array}$ & $\begin{array}{c}\text { Mengelola } \\
\text { Pembelajaran }\end{array}$ \\
\hline Kompetensi Pedagogik & Pearson Correlation & 1 & $.335^{* *}$ \\
& Sig. (1-tailed) & & .000 \\
& $N$ & 144 & 144 \\
Kemampuan Mengelola & Pearson Correlation & $.335^{* *}$ & 1 \\
Pembelajaran & Sig. (1-tailed) & .000 & 144 \\
& $N$ & 144 & \\
$* *$ *. Correlation is significant at the 0.01 level (1-tailed). & & \\
\hline
\end{tabular}

Berdasarkan analisis data menggunakan uji korelasi pearson product moment, diketahui bahwa terdapat hubungan positif yang signifikan antara kompetensi pedagogik dan kemampuan mengelola pembelajaran dengan koefisien korelasi sebesar 0,335 dan diketahui $r$ table sebesar 0,137 sehingga Sig. (1-tailed) yaitu 0,000 ( $p$ value $<0,05$ ). Nilai 0,05 adalah taraf signifikansi yang digunakan pada penelitian ini. Sesuai dengan hasil uji korelasi tersebut, maka hipotesis yang menyatakan bahwa terdapat terdapat hubungan yang positif dan signifikan antara kompetensi pedagogik dan kemampuan mengelola pembelajaran pada guru SD sekecamatan Pacitan dapat diterima. Hasil analisis koefisien korelasi antara variabel kompetensi pedagogik dan kemampuan mengelola pembelajaran yaitu 0,335 artinya $r$ hitung $>r$ table yaitu sebesar 0,137 , maka terdapat hubungan positif antara kompetensi pedagogic dan kemampuan mengelola pembelajaran pada guru SD sekecamatan Pacitan. Berdasarkan pendapat Alaydrus \& Sarwono (2018: 102)mengenai pedoman interpretasi terhadap koefisien korelasi menyatakan bahwa koefisien korelasi pada penelitian ini yaitu 0,335 berada pada tingkat hubungan sedang/moderat.

Sesuai hasil perhitungan sumbangan kompetensi pedagogik dan kemampuan mengelola pembelajaran sebesar $11,2 \%$ dan sisanya sebesar $88,8 \%$ dipengaruhi oleh faktor lain. Menurut Lufri, dkk (2020: 313) sumbangan efektif kecil dapat disebabkan karena suatu variabel bebas yang berada bersama-sama dengan variabel bebas yang lain dalam persamaan regresi, peranannya sebagai prediktor variabel terikat dapat 
ditekan oleh variabel lain. Hal ini dapat dipahami bahwa masih banyak faktor lain, disamping faktor kompetensi pedagogik yang dapat memengaruhi kemampuan mengelola pembelajaran pada guru SD.

Hasil penelitian ini sejalan dengan penelitian Widiawahyuni (2015:14), yang menyatakan bahwa kompetensi pedagogik memiliki pengaruh yang signifikan terhadap kemampuan guru dalam mengelola kegiatan pembelajaran IPS di SMP Negeri kota Singaraja. Hasil penelitian tersebut juga diperkuat oleh penelitian Afriyanti (2015:8), yang menyatakan bahwa terdapat pengaruh yang signifikan kompetensi pedagogik terhadap kinerja guru Sekolah Dasar Gugus Sadewa dan Bima Kecamatan Kutowinangun Kabupaten Kebumen sebesar 36,9\% dan sisanya 63,1\% ditentukan oleh faktor-faktor lain.

Hasil perhitungan sumbangan efektif pada variabel kompetensi pedagogik dan kemampuan mengelola pembelajaran pada guru SD didapatkan hasil sebesar $11,2 \%$, artinya kompetensi pedagogik yang dimiliki guru dapat berperan dalam meningkatkan kemampuan mengelola pembelajaran pada guru SD sebesar $11,2 \%$ dan sisanya sebesar $88,8 \%$ dipengaruhi oleh faktor lain seperti latar belakang pendidikan guru, motivasi guru, faktor kurikulum, metode mengajar, faktor relasi, disiplin sekolah, alat pelajaran, standar pelajaran, dan faktor lingkungan sekitar.

\section{SIMPULAN}

Berdasarkan hasil penelitian dan pembahasan mengenai kompetensi pedagogik dan kemampua mengelola pembelajaran pada guru SD sekecamatan Pacitan dapat ditarik kesimpulan bahwa kompetensi pedagogik berkorelasi positif dan signifikan dengan kemampuan mengelola pembelajaran pada guru SD sekecamatan Pacitan dengan tingkat korelasi sedang yaitu 0,335 . Hal tersebut berarti apabila kompetensi pedagogik yang dimiliki guru baik, maka akan menjadikan guru mampu mengelola kegiatan pembelajaran dengan maksimal dan sebaliknya, apabila kompetensi pedagogik yang dimiliki oleh guru masih rendah maka kemampuan dalam mengelola pembelajaran juga tidak maksimal.

Sumbangan variabel kompetensi pedagogik terhadap kemampuan mengelola pembelajaran sebesar $11,2 \%$ dan sisanya $88,8 \%$ dipengaruhi oleh faktor lain seperti latar belakang pendidikan guru, motivasi guru, faktor kurikulum, metode mengajar, faktor relasi, disiplin sekolah, alat pelajaran, standar pelajaran, dan faktor lingkungan sekitar.

\section{DAFTAR PUSTAKA}

Afriyanti,M. (2015). Pengaruh Kompetensi Pedagogik Terhadap Kinerja Guru Sekolah Dasar Gugus Sadewa dan Bima Kecamatan Kutowinangun Kabupaten Kebumen. Under Graduates thesis, UNIVERSITAS NEGERI SEMARANG.

Alaydrus, A.M. \& Sarwono. (2018). Analisis Faktor Keterlambatan Dimulainya Pelaksanaan Proyek Kontruksi pada Model Kontrak Rancang Bangun. Jurnal Konstruksia, 10 (1), 95-116.

Hamdani. (2017). Hubungan Kompetensi Pedagogik dan Motivasi Mengajar dengan Hasil Belajar Siswa Kelas XI pada Mata Pelajaran Fikih di MAN 2 Model Medan. Jurnal ANSIRU Nomor 1 Volume 1 Hal.48.

Lufri, dkk. (2020). Metodologi Pembelajaran: Strategi, Pendekatan, Model, Metode Pembelajaran. Malang: CV. IRDH.

Pamela, I. S, dkk (2019). Keterampilan Guru dalam Mengelola Kelas. Edustream: Jurnal Pendidikan Dasar Volume III, Nomor 2, November 2019 E-ISSN: 26144417.

Srijani, J. (2013). Pengelolaan Uji Kompetensi Pedagogi Guru Kelas VI SD di Kecamatan Pacitan. Naskah Publikasi Program Pascasarjana UMS. 
Widiawahyuni, N. (2015). Pengaruh Kompetensi Pedagogik Terhadap Kemampuan Guru dalam Mengelola Kegiatan Pembelajaran IPS di SMP Negeri Kota Singaraja. Jurnal Jurusan Pendidikan Ekonomi (JJPE) Volume: 5 Nomor: 1 Hal.2. 